\title{
THE PLACE OF THE COLLEGE IN TRAINING TEACHERS TO EDUCATE STUDENTS AND THE GENERAL PUBLIC IN CONSERVATION*
}

\author{
RICHARD L. WEAVER \\ School of Natural Resources, University of Michigan, Ann Arbor, Mich.
}

With the increasing emphasis on conservation and resource-use education in public schools, there naturally arises a need for colleges to initiate or to increase their teacher training efforts in this field of instruction.

The criteria for planning such a program should be clearly defined and cooperatively developed if possible, inasmuch as many interests are involved.

Some of these criteria are specific to conservation and resource-use education, but many of them apply equally well to many fields of instruction. Some that find general acceptance among conservationists and educators are:

1. Conservation demands an understanding of specific resources and problems involved in their use, but also of the interrelatedness of the resources one to another.

This requires information on the a) nature of soils, forests, water minerals, and wildlife, b) on the extent and future prospects for the resource, $\mathrm{c}$ ) on the problems of extraction and use, d) on the management techniques available to increase or extend the resource, and e) on the administrative agencies and procedures established for the application of the technical "know-how" to the resolution of the problems.

The interrelatedness of resources is expressed as ecology.

Colleges usually have a general or an introductory course in Conservation or Resource-use which covers the specific resources. Some attention to the recreational resources and the human resources is given in most texts used in these courses.

Some colleges and universities such as the University of Michigan, Michigan State University, Purdue University and Wisconsin State College at Stevens Point have individual courses covering most of the basic resources. Some colleges also have special courses in ecology which help students see the broad interrelationships.

The Science departments or Conservation departments are the logical ones to handle the technical aspects of resource management found in these introductory or specific courses.

\footnotetext{
* Read at the Conservation Section of the Central Association of Science and Mathematics Teachers at De* troit, November 25, 1955.
} 
However many geography departments have given such introductory courses and occasionally a course in mineral conservation.

2. Conservation and Resource-use today demands an understanding of resource-economics, and resource-politics at the state, national and international levels.

Some of these understandings can be incorporated into introductory courses, but usually they also need to be dealt with at greater lengths in specialized courses.

Here social science departments and particularly people especially trained in conservation can best cover these aspects of conservation.

At the University of Michigan we have two introductory courses, one emphasizing conservation in the United States, the other conservation in Michigan. Then in addition we have a course on International Resource problems, and another one on Resource Economics.

Some teachers' colleges have an introductory course for social studies majors and another one for science majors.

3. Conservation and Resource-use education demands instruction and experiences in some specialized educational techniques such as leading field trips, using resource people and community resources, problemsolving, using and developing audio-visual aids, using school forests, gardens, and camps, and developing units of study emphasizing local resource-use problems.

These are the techniques which will enrich teaching generally but are especially useful in teaching conservation and resource-use.

Such techniques cannot be learned from a text anymore than the nature or characteristics of specific resources.

Students planning to teach need real-life experience in the use of these techniques with children and adults.

Frequently workshops are designed as special methods courses where such experiences can be provided. Workshops also envision the development of units or plans of action which relate the content in conservation to specific school situations.

In one of our content courses, the one dealing with Michigan Resources I have the students do the research and planning necessary for them to present all of the content of the course, using as many of the above techniques as possible. Regular evaluations are necessary and checking of the outlines and plans as they are developed, if this plan is used.

4. Conservation and Resource-use education demands a considerable emphasis on local resources and resource problems.

Thus textbooks prepared for national use in public schools are not 
as helpful as in some fields. If a text is used, it needs to be supplemented greatly.

Teachers being prepared for teaching conservation need experience in the development of units and projects in which the local resources are used and studied.

We provide this at the University of Michigan through several means a) experience in teaching a part of the course on Michigan resources b) development of units and some leadership experiences in the conservation workshop, and c) work experience by assisting in school camp, talking to assemblies, leading field trips, and assisting teachers locally with conservation projects. We have a conservation club through which these requests are channeled.

\section{Conservation and Resource-use education should include information concerning human resources and relationships.}

Such things as the origin and characteristics of the population, their cultural backgrounds and mores, their use of technical information, their employment, education, health, recreational opportunities and their concern for wise resource-use all should be considered a part of our conservation and resource-use picture.

The way people work together and the manner in which they take on new ideas or can be influenced to give leadership to a particular effort are new areas for many colleges and teachers. The behavior of groups, why they succeed or fail, and how they can improve is probably one of our best avenues for greater progress in conservation and wise resource-use.

This new emphasis, called group dynamics can express itself in classrooms by better methods of organizing our work, by small groups cooperatively planning and executing certain parts of the study, by decentralizing some of the work, and by evaluating all of the procedures and results regularly.

Workshops lend themselves especially well to the demonstration and use of these techniques, although parts of them can also be incorporated into other types of courses. I use some of these in the course on Michigan resources, where the students present the content information.

6. Conservation and Resource-use education requires mastery of the communication skills.

Some, in fact most of our school subjects do not anticipate any specific immediate action resulting from the instruction.

Conservation and wise resource-use recognizes the need for improvement and change in the application of "technical know-how" and "ethical-practices." It is built upon proper attitudes and be- 
havior patterns. Thus there's more of a "missionary incentive" involved.

This requires greater emphasis on our ability to use speech, debate, the printed word, radio, television and other audio-visual aids in getting ourselves understood and bringing about behavioral changes.

Thus colleges need to increase their emphasis on this and provide greater opportunities to have rich experiences in these techniques.

Teachers cannot be expected to improve their abilities in these things merely by observing a master teacher using them effectively. In fact many college teachers do not even demonstrate them very effectively.

In our University of Michigan program of training teachers and other conservation leaders, we are endeavoring to get a three-way balance in our instruction at the graduate as well as the undergraduate level. We prefer a third emphasis on the natural sciences, a third on the social sciences and another third on the communication skills.

We have an undergraduate major in conservation in which a teaching certificate can be obtained, a master's sequence in conservation and outdoor education in the School of Education, as well as a master's and doctor's program in conservation in the Graduate School.

Many of our faculty have joint appointments in other departments, such as botany, zoology, economics and education.

We try to keep our scientists in close touch with teachers' problems by having many of them assist with off campus courses for teachers. One operated for ten weeks requires ten staff members, each leaving the campus for a week at a time and appearing at five course centers during the week.

\section{SUMMARY}

1. Colleges need to re-examine their courses and programs in conservation and resource-use in the light of the new demands being made upon them.

2. All colleges and universities need at least one introductory course in conservation which covers the basic resources and the principles of resource-use. Additional specialized courses are needed to adequately prepare teachers wanting to specialize in conservation. Areas frequently omitted are resource economics, international aspects of resource development, and ecology.

3. A methods course or conservation and resource-use workshop is essential if experiences are to be provided in many of the techniques which have special application to conservation and resource-use education such as field trips, audio-visual, problem-solving, group 
dynamics, school camps, forests, gardens and other outdoor laboratories.

4. Teachers need practical work experiences with emphasis on "How to do it," and opportunities for them to develop their own skills in the numerous techniques necessary for enriched learning in conservation and resource-use.

\section{REFERENCES}

1. American Institute of Biological Sciences Bulletin, January 1954, "Training the Conservation Worker," a Symposium by Hall, McCabe, Lagler, Marshall and Weaver. Available from NABT Conservation Project, P.O. Box 2073, Ann Arbor, Michigan. 10 cents.

2. American Council on Education, Committee on Southern Regional Studies and Education-Guide for Resource-use Education Workshops, 46 pages, $50 \notin$; 1785 Massachusetts Avenue, N. W., Washington 6, D. C.

3. National Association of Biology Teachers-Handbook for Teaching Conservation and Resource-use, 500 pp. 1955. P.O. Box 2073, Ann Arbor, Michigan.

\section{TEACHING AS A CAREER}

Teaching as a Career. By Earl W. Anderson. Office of Education Bulletin 1955, No. 2. 20 pages. For sale by the Superindendent of Documents, U. S. Government Printing Office, Washingron 25, D. C. 15 cents.

Any young man or woman who is considering teaching as a career should seek answers to the following questions: How important is teaching? What does a teacher do? What are the requirements for teaching? How may I meet them? How can I give satisfactory employment in teaching? What salary will I receive? What are the retirement provisions? Will I enjoy teaching? Answers to these questions are given in Teaching as a Career.

In this bulletin of the Office of Education; it is pointed out that capable young people prepared for teaching will find great demand for their serivces in the immediate years ahead. It is expected that the present critical need for qualified elementary school teachers will continue for many years. In addition, the present shortages of high school and college teachers in mathematics, science, and technical fields will, according to predictions, spread to virtually all subjects as the large numbers of students now in the elementary schools move on into the high schools and later into the colleges.

Teaching as a Career is published as a much-needed service to men and women considering preparation for teaching.

\section{ECOLOGY CENTER ESTABLISHED AT WESTERN MICHIGAN}

As the result of a very generous gift and the hard work of some Western Michigan College faculty members, the local campus may well become one of the World's leading centers for information in the field of ecology.

Just received on the campus is the first half of the library of the late Dr. Charles C. Adams, former president of the Ecological Society of America and acknowledged to be one of the world's foremost ecologists before his death last April in Albany, N. Y., at the age of 82 .

The entire collection has been valued by two independent dealers at between $\$ 30,000$ and $\$ 40,000$. Some idea of the extent of the books and pamphlets may be gathered from the fact that this initial shipment weighed 11,000 pounds. 